\title{
Geotechnology applied to predict the risk of occurrence of fire in the Atlantic Forest
}

The maintenance of biodiversity is a global concern in economic, social and environmental terms. Thus, conservation units for the protection of natura environments were created. Despite the importance of these areas, forest fires have caused immeasurable and constant damage to Conservation Units. In view of this, the objective of this study was to determine the risk areas of forest fire occurrence through Fuzzy logic modeling in the Córrego Grande Biological Reserve, located in the Mata Atlântica Brazilian biome. In order to prospect for areas at risk of forest fires, the following variables were inserted in the model: land use, road network, slope and relief orientation. Finally, the model was validated by comparing the location of fire occurrences between the years 2008 and 2018 , and a layout of the risk classes in the study area. In doing so, it was found that $65.87 \%$ of the area is between the 'moderate' and 'very high' range of fire risk classes, and that $70.22 \%$ of the fires which occurred in the studied period also occurred in that class range. The study concluded that the most influential variable on the risk level of fire occurrence is the forest road network. In this way, the proposed methodology can be applied to any other areas and types of land cover.

Keywords: Forest protection; Fuzzy logic; Conservation areas.

\section{Geotecnologia aplicada para predizer o risco de ocorrência de incêndio na Mata Atlântica}

\begin{abstract}
A manutenção da biodiversidade é uma preocupação global em termos econômicos, sociais e ambientais. Assim, foram criadas unidades de conservação para a proteção de ambientes naturais. Apesar da importância dessas áreas, os incêndios florestais têm causado danos incomensuráveis e constantes às Unidades de Conservação. Diante disso, o objetivo deste estudo foi determinar as áreas de risco de ocorrência de incêndios florestais por meio de modelagem em lógica Fuzzy na Reserva Biológica do Córrego Grande, localizada no bioma Mata Atlântica. Para a prospecção de áreas com risco de incêndios florestais, foram inseridas no modelo as seguintes variáveis: uso do solo, malha viária, declividade e orientação do relevo. Por fim, o modelo foi validado comparando a localização das ocorrências de incêndio entre os anos de 2008 e 2018, e um layout das classes de risco na área de estudo. Ao fazê-lo, verificou-se que $65,87 \%$ da área está entre as classes de risco de incêndio 'moderado' e 'muito alto', e que 70,22\% dos incêndios ocorridos no período estudado também ocorreram nessa faixa de classe. 0 estudo concluiu que a variável mais influente no nível de risco de ocorrência de incêndios é a malha rodoviária florestal. Desta forma, a metodologia proposta pode ser aplicada a quaisquer outras áreas e tipos de cobertura do solo.
\end{abstract}

Palavras-chave: Proteção florestal; Lógica difusa; Áreas de conservação.

Topic: Tecnologia, Modelagem e Geoprocessamento

Reviewed anonymously in the process of blind peer.
Received: 02/01/2021

Approved: $28 / 01 / 2021$
Antonio Henrique Cordeiro Ramalho (iD

Universidade Federal do Espírito Santo, Brasil http://lattes.cnpq.br/7064955262943008 http://orcid.org/0000-0002-0037-5422

henriquecr2012@hotmail.com

Eleon de Castro Neder (iD

Universidade Federal do Espírito Santo, Brasil http://lattes.cnpq.br/2359216971468870 http://orcid.org/0000-0002-9408-8140

decastroflorestal@hotmail.com

\section{Nilton Cesar Fiedler (iD}

Universidade Federal do Espírito Santo, Brasil http://lattes.cnpq.br/8699171075880935 http://orcid.org/0000-0002-3895-661X niltoncesarfiedler@yahoo.com.br

\author{
Taís Rizzo Moreira (iD) \\ Universidade Federal do Espírito Santo, Brasil \\ http://lattes.cnpq.br/6717864186103246 \\ http://orcid.org/0000-0001-5536-6286 \\ taisr.moreira@hotmail.com \\ Jeferson Pereira Martins Silva (iD) \\ Universidade Federal do Espírito Santo, Brasil \\ http://lattes.cnpq.br/6748966859692740 \\ http://orcid.org/0000-0003-1552-1127 \\ jefersonsb09@hotmail.com
}

Referencing this:

RAMALHO, A. H. C.; NEDER, E. C.; FIEDLER, N. C.; MOREIRA, T. R.; SILVA, J. P. M.. Geotechnology applied to predict the risk of occurrence of fire in the Atlantic Forest. Revista Ibero Americana de Ciências Ambientais, v.12, n.1, p.707-720, 2021. DOI: http://doi.org/10.6008/CBPC2179-6858.2021.001.0057 


\section{INTRODUCTION}

Maintaining biodiversity is a global concern and has immeasurable economic, social and environmental values. However, disordered population growth, the consequent anthropogenic interference and climate change have threatened flora and fauna species on all continents (PRENTICE et al., 2019).

The possible destruction of natural environments and the eradication of species threatened with extinction forced government officials to establish policies for creating conservation units (CU) with the aim of protecting natural environments, ensuring the preservation of biodiversity (OLIVEIRA et al., 2016). According to Law 9,985 of July 2000, CUs are classified as Integral Protection Units which only allow the indirect use of natural resources and/or Sustainable Use, which only allows the sustainable use of part of their natural resources (BRASIL, 2000). Biological Reserves, the target of this research, are inserted in the integral protection group.

Despite the ecological, economic and social importance of conservation units, according to Telbadi et al. (2013), forest fires in these areas are considered threats to these environments. Between 2010 and 2018, the Ministry of the Environment (MMA) recorded an average of approximately 1 million hectares per year of conservation unit areas destroyed by forest fires in Brazil.

A forest fire is any fire without control and has destructive power which occurs in vegetation, being initiated by human or natural actions (TETTO et al., 2015; EUGENIO et al., 2016; MOTA et al., 2019). These situations enhance the formation of forest fragments, the destruction of biodiversity, material goods and even human lives, increase erosion rates, soil compaction, runoff, and consequently silt up water bodies (HERAWATI et al., 2011; MORA et al., 2016; MURILLO et al., 2016; VAN ECK et al., 2016; TORRES et al., 2017a).

Due to the destructive power of these fires, a search for effective methods of predicting their occurrence is essential for managing bodies of the CU. According to Eugenio et al. (2016), a methodology capable of providing subsidies to minimize the adverse effects of fires is the zoning of risks of occurrence of forest fires through an association of partial risk maps of different biological, physical and anthropic variables (WHITE et al., 2016) through artificial intelligence techniques implicit in Geographic Information Systems (GIS), more precisely called Fuzzy logic.

The maps developed during the risk zoning processes using Fuzzy logic have information capable of assisting the application of prevention techniques, strategic allocation of combat teams and consequently reducing the occurrence of forest fires. This methodology has a wide scope in predicting and mapping environmental disasters such as in the assessment of flood risk (CAl et al., 2019), determining the resilience power of urban structures after seismic events (ANDRIĆ et al., 2017), and decision support for mass evacuations of cities prone to coastal or river floods (JIA et al., 2016), among others.

The present study was developed under the hypothesis that the use of a Fuzzy logic model can be applied to predict the occurrence of forest fires. Thus, the objective was to determine the risk areas of forest fire occurrence through Fuzzy logic modeling inserted in the interior and in the buffer zone of the Córrego Grande Biological Reserve, located in the interior of the Mata Atlântica Brazilian biome. 
The main justification for carrying out the present study is the concern with the representativeness of the region which integrates one of the main Atlantic Forest biome remnants of the states and Brazil. This biome includes one of the most diverse forests on the planet and is considered one of the 35 global hotspots. In addition, the Biological Reserve is home to a rich diversity of flora and fauna (MYERS et al., 2003; MURRAYSMITH et al., 2009; BRANCO et al., 2019).

\section{MATERIALS AND METHODS}

\section{Study area}

The present study was carried out in the Córrego Grande Biological Reserve and in its buffer zone located in the municipality of Conceição da Barra in the state of Espírito Santo and Mucuri in the state of Bahia. The study area comprises a total of 14,597 hectares of protected areas and is located between the meridians $39 \circ 44^{\prime} 24^{\prime \prime}$ to $39 \circ 52$ ' $10^{\prime \prime}$ west longitude of Greenwich and the parallels $18 \circ 11^{\prime} 12^{\prime \prime}$ to $18 \circ 20^{\prime} 45^{\prime \prime}$ south latitude (Figure 1).

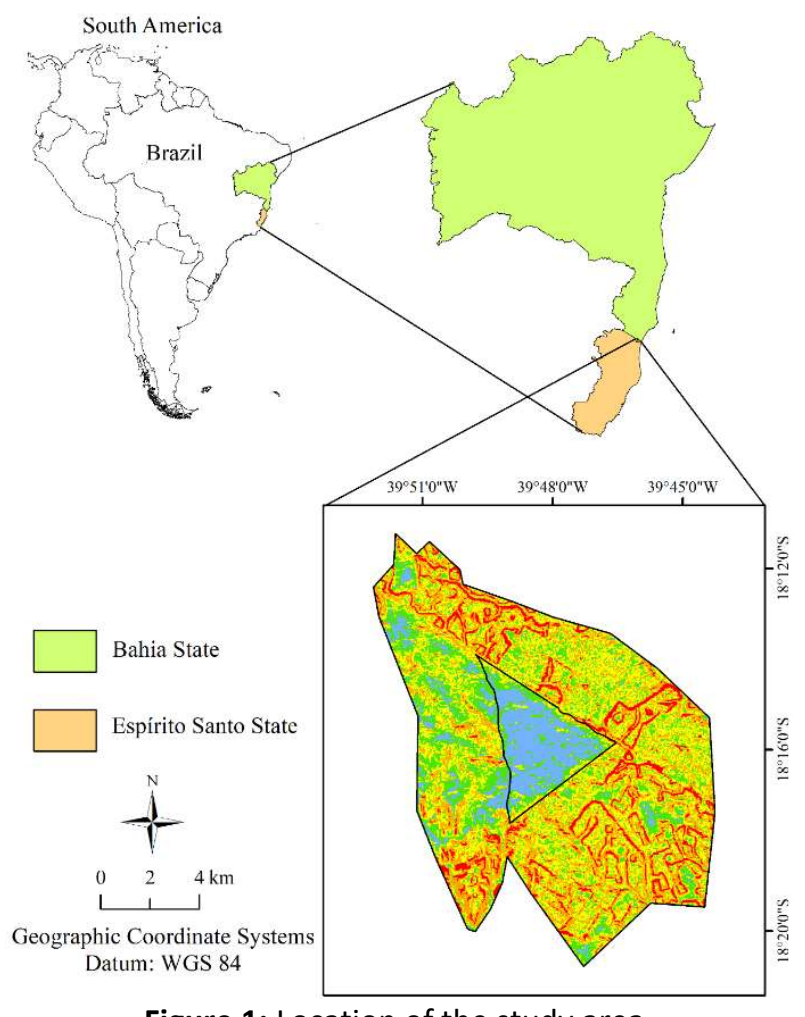

Figure 1: Location of the study area.

The study area is completely covered by the Af type (humid tropical) climate according to the Köppen climate classification, with an average annual rainfall of $1200 \mathrm{~mm}$ and an average annual temperature of 23.3 oC (ROLIM et al., 2007; ALVARES et al., 2014). The area is covered by the Atlantic Forest biome and dense ombrophilous forest formations (SOARES et al., 2013). The relief is flat to smooth wavy. The altitude does not exceed 300 meters. 


\section{Methodological steps}

\section{Database development}

Biological (land use), physical (relief orientation and slope) and socioeconomic (proximity to roads) variables were used to elaborate the forest fire risk map (RFFO) of the study area. Photointerpretation techniques of aerial images available in the basemaps of the ArcGis version 10.3 software program were used for mapping the land use (LU) and the road network (RN). The images used have a spatial resolution of $1 \mathrm{~m}$ and the scale used for photointerpretation was 1:1,500. The LU classes present in the study area were: Eucayptus sp. plantations, water courses, native forests in the medium/advanced regeneration stage, native forests in the initial regeneration stage, flooded areas, dirty fields, macaque, agricultural crops, pasture, exposed soil, built-up areas, water reservoirs and unpaved roads.

Some classes were defined during the delimitation of the road network according to the characteristics of the roads. Buffers were applied to determine the variable proximity to roads in order to determine the influence of each of these roads on the occurrence of fire outbreaks. The road classes, description, perimeter and influence determination buffers for each are listed in Table 1.

Table 1: Classification of the road network of the study area.

\begin{tabular}{llll}
\hline Classes & Description & Buffer $(\mathrm{m})$ & Perimeter (km) \\
\hline Primary & Width higher than 5 meters & 100 & 42.38 \\
Secondary & Width of 4 to 5 meters (roads of eucalyptus stands) & 50 & 986.49 \\
Tertiary & Width of 3 to 4 meters (access roads to Biological Reserve) & 25 & 1.17 \\
\hline Total & - & - & 1030.04 \\
\hline
\end{tabular}

The Digital Elevation Model (MDE) was used to elaborate the slope and relief orientation maps, derived from a matrix image of the topographic radar mission Shuttle (SRTM) with spatial resolution of 30 meters. Such maps were made using tools provided in ArcGis version 10.3, with the clinical map created using the Slope tool and the relief orientation using the Aspect tool, both present in the Spatial Analyst Tools extension.

\section{Conversion of land use maps}

After quantifying the area of each land use class using the geometric calculator in $\operatorname{ArcGis}^{\oplus}$ version $^{\circ}$ 10.3, the vector image was converted to a matrix image in order to prepare it for applying the Fuzzy logic model. A reclassification was subsequently elaborated in relation to the influence that each class has on the risks of forest fires.

\section{Euclidean distance in the road mesh variable}

The influence of the proximity of the roads was defined from applying the Euclidean distance. This is a measure which defines the distance between the center of two cells in a straight line. The distance between two points $D_{A B}\left(X_{A}, Y_{A}\right)$ and $\left(X_{B}, Y_{B}\right)$ on a plane is calculated by the Pythagorean Theorem. 


\section{Application of Fuzzy logic model}

Fuzzy logic was used to model the risks of forest fires in the study area, which enables translating a qualitative value into a numerical value belonging to a set of values in the range between 0 and 1 (GAGLIONE et al., 2019). Thus, different pertinence functions were defined for the application of Fuzzy logic in each of the variables used, in which the RFFO was considered very high when the variable assumes values in the Fuzzy set close to 1 , and very low when they approach 0 .

The choice for the appropriate pertinence function was due to the better adequacy of the influence of the variables on the risks of forest fires. To this end, bibliographic surveys were conducted which are capable of assisting in this definition.

The Fuzzy Gaussian pertinence function was applied for the land use variable, which defines a normal distribution around a defined central point with a curve slope value between 0.01 and 1 (Equation 1). The class defined as the central point assumes the value 1 of the Fuzzy set, meaning the class with the greatest influence on the RFFO. The extremity classes assume equal values and consequently those with less influence on the occurrence of forest fires.

$$
\mu(x)=\exp ^{-\alpha^{*}(x-a)^{2}}
$$

Where, $\alpha$ is the slope parameter of the curve; $x$ is the value of the land use class; and a refers to the midpoint of the function at which $\mu(x)$ takes the value 1 .

The matrix image of land use (LU) was reclassified with values ranging from 0 to 12 , according to the influence of each class (Table 2).

Table 2: Land use reclassified according to the influence on the risks of forest fire occurrence.

\begin{tabular}{ll|ll}
\hline Classes of land use & Reclassified value & Classes of land use & Reclassified value \\
\hline Watercourse & 0 & Weed & 7 \\
Exposed Soil & 1 & Built Area & 8 \\
Initial Forest & 2 & Pasture & 9 \\
Dirty Field & 3 & Flood Area & 10 \\
Unpaved roads & 4 & Medium/Advanced Forest & 11 \\
Agriculture Field & 5 & Water Reservoir & 12 \\
Eucalyptus plantations & 6 & - & - \\
\hline
\end{tabular}

Eucalyptus plantations were defined as the class with the greatest influence on forest fire risks based on White et al. (2014), who state that the accumulation of combustible material in these environments facilitates fire spread and the occurrence of high-intensity fires. As the water courses and reservoirs do not have the presence of combustible materials, they were considered to be of low influence on fires.

The pasture and dirty field classes were classified as having medium influence on the RFFO for presenting large extensions of land covered by herbaceous plants close to family farming areas which are commonly managed with the use of fire (MACHADO NETO et al., 2015). Unpaved roads and built-up areas were classified with the same degree of influence on fire risks as they are in constant anthropic changes. The areas of macaque and agricultural crops were defined with a matrix value 7 and 5, as they are areas with the presence of anthropic disturbances and therefore present vulnerability to fires.

The Fuzzy Gaussian was applied after the reclassification, with a range from 0 (very low) to 1 (very high), with the very high risk being reclassified to the value of 6 . The results of this procedure gave rise to the 
RFFO map due to the influence of the land use variable.

We opted for the use of the Fuzzy Small relevance function when elaborating the influence map of the proximity of roads on the risk of forest fires, determining that the closer to the road, the greater the risk of fire occurrence. Thus, the value of the central point in the Fuzzy set confers a relevance degree of 0.5 in the function with a curve propagation degree of 1-10 (Equation 2).

$$
\mu(x)=\frac{1}{1+\left(\frac{x}{c}\right)^{b}}
$$

Where, $x$ is the value of the distance from the roads $(m) ; b$ refers to the slope parameter of the curve; and $c$ is the midpoint of the function at which $\mu(x)$ takes the value 0.5 .

To apply the Fuzzy logic model under the Small membership function, the operator must include an input value under the influence of the variable in the model (Midpoint). Therefore, this value was defined based on the studies of Juvanhol et al. (2015) and Soto (2012), and so the Midpoint value of 300 meters and the spread rate of 3 were defined in the layout and distribution of the road network of the study area so that the shortest distances from the roads assume higher values of the degree of fuzzy relevance.

According to Mota et al. (2019) and Naderpour et al. (2019), the greater the slope of the terrain, the greater the chance of forest fires occurring and spreading. Thus, the Fuzzy Large membership function was applied to analyze the influence of the slope on the RFFO, which points out that the greater the slope of the terrain, the greater the risk of fires occurring (value of 1 in the Fuzzy set). The the central point value gives a relevance degree of 0.5 in the function with a curve propagation degree of 1-10 (Equation 3).

$$
\mu(x)=\frac{1}{1+\left(\frac{x}{e}\right)^{-d}}
$$

Where, $\mathrm{x}$ is the slope value (o); $\mathrm{d}$ is the slope parameter of the curve; and e refers to the midpoint of the function at which $\mu(x)$ takes the value 0.5 .

The influence of the relief orientation on the RFFO is related to the variation of the solar incidence and wind intensity as a function of the exposure faces of the terrain. The Fuzzy Generalized Bell membership function was used to model the relief orientation variation and the transition zone values of the set assume a relevance degree of 1 (Equation 4), according to the risk of fire.

$$
\mu(x)=\frac{1}{1+\left(\frac{x-f}{g}\right)^{2 h}}
$$

Where, $\mathrm{x}$ is the relief orientation value (o); $\mathrm{g}$ is the slope parameter of the curve; $\mathrm{c}$ refers to the midpoint of the function at which $\mu(x)$ takes the value 1 ; and $h$ controls the amplitude of the central point.

The north face ( 0 을 and 360 ) $)$ was considered as the highest risk and the South face (180) as the lowest risk. The flat relief was considered to be of very low risk (Table 3).

Table 3: Relief orientation according to the influence on risks of forest fire occurrence.

\begin{tabular}{ll|ll}
\hline Orientation & RFFO & Orientação & RFFO \\
\hline Flat (0) & Very Low & South $(157.5-202.5 \circ)$ & Very Low \\
North $(0-22.5 \circ)$ & Very High & Southwest $(202.5-247.5 \circ)$ & Low \\
Northeast $(22.5-67.5 \circ)$ & High & West $(247.5-292.5 \circ)$ & Regular \\
East $(67.5-112.5 \circ)$ & Regular & Northwest $(292.5-337.5 \circ)$ & High \\
Southeast $(112.5-157.5 \circ)$ & Low & North $(337.5-360 \circ)$ & Very Low \\
\hline
\end{tabular}




\section{Fuzzy overlay}

The influence variables were combined in modeling for prospecting forest fire risk zones in the geographic information systems environment through the overlap analysis in order to point out the probability of the cells in the matrix image of a model variable being included in the Fuzzy set of the other variables using different entry criteria. The overlay method used was the Fuzzy Gamma (Equation 5).

$$
\mu(x)=\left\{1-\prod_{i=1}^{n}(1-\mu i)\right\}^{y} *\left\{\prod_{i=1}^{n} \pi_{i}\right\}^{1-y}
$$

Where, $\mu_{\mathrm{i}}$ refers to the Fuzzy association values; $\mathrm{n}$ is the number of variables; and $\mathrm{y}$ is the coefficient value, between 0 and 1.

The " $y$ " coefficient was defined with its standard value (0.9) so that it was possible to achieve the combined effect between the product and the sum. It is possible to combine the increasing effect of the Fuzzy sum with the Fuzzy Gamma and the decreasing effect of the Fuzzy product and not simply return to a single Fuzzy set.

\section{Model validation}

According to Pickard et al. (2019), validation is a way to raise confidence levels that modeled events will occur under conditions imposed by the real world. The occurrence maps of hot spots observed between the years 2008 to 2018 from the detection system of the National Institute for Space Research (INPE), and the correlation of the data for rainfall figures for the São Mateus weather station between 2008 and 2018 were also used in this study to analyze the reliability of the Fuzzy modeling.

The flowchart with the necessary methodological steps for prospecting risk zones for forest fires in the Córrego Grande Biological Reserve and its buffer zone is shown in Figure 2.

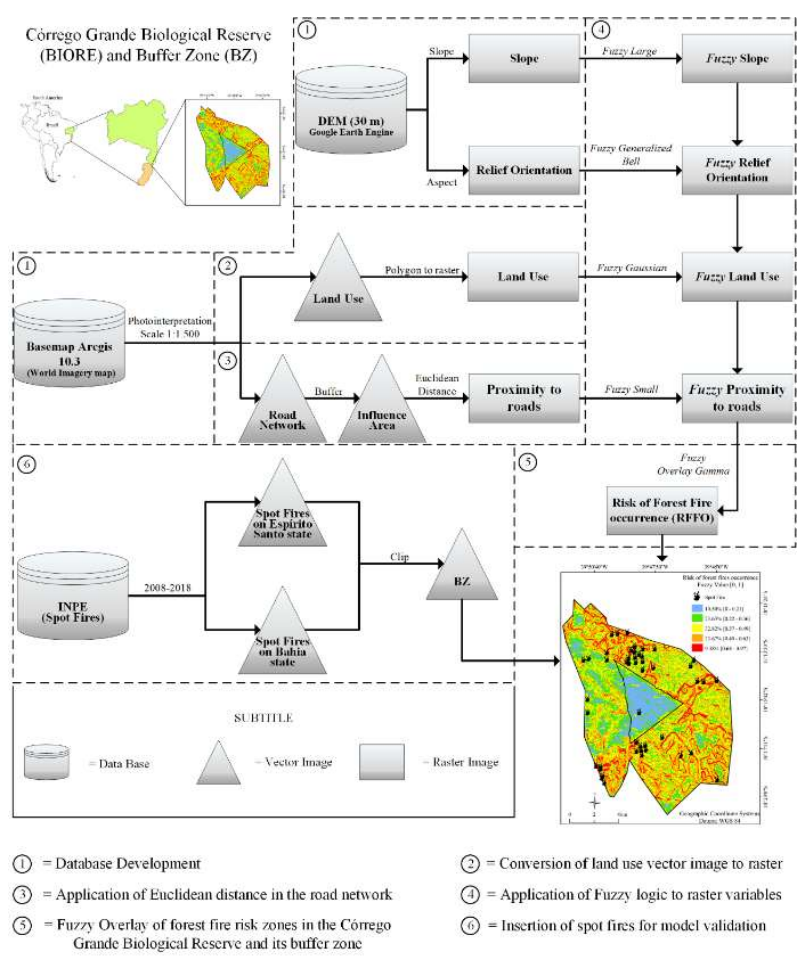

Figure 2: Methodological flowchart for the elaboration of the risk zoning for the occurrence of forest fires in the Biological Reserve of Córrego Grande and its buffer zone. 


\section{RESULTS}

Figure 3 shows the maps representing the distribution of classes of land use, road network, slope and relief orientation in the study area. Table 4 shows the distribution by area of land use classes in the study area.

Table 4: Area in hectares per class of land use in the study area (BIORE and BZ).

\begin{tabular}{llll}
\hline \multirow{2}{*}{ Classes } & Area (ha) & & \\
\cline { 2 - 4 } & Biological Reserve & Buffer Zone & Total \\
\hline Eucalyptus plantations & 3.85 & $5,758.72$ & $5,762.58$ \\
Agriculture Field & 0.00 & 66.24 & 66.24 \\
Exposed Soil & 1.07 & 70.37 & 71.44 \\
Built Area & 0.00 & 2.18 & 2.19 \\
Flood Area & 34.29 & 245.99 & 280.28 \\
Dirty Field & 6.43 & 211.74 & 218.17 \\
Initial Forest & 11.24 & 124.86 & 136.10 \\
Watercourse & 0.00 & 27.03 & 27.03 \\
Medium/Advanced Forest & $1,407.17$ & $3,143.68$ & $4,550.85$ \\
Pasture & 18.57 & $2,901.17$ & $2,919.74$ \\
Water Reservoir & 0.00 & 20.46 & 20.46 \\
Weed & 0.00 & 46.49 & 46.49 \\
Unpaved roads & 1.74 & 494.13 & 495.87 \\
\hline Total & $1,484.38$ & $13,113.07$ & $14,597.44$ \\
\hline
\end{tabular}

Figure 4 represents the Fuzzy set values for the variables of land use, road network, slope and relief orientation.

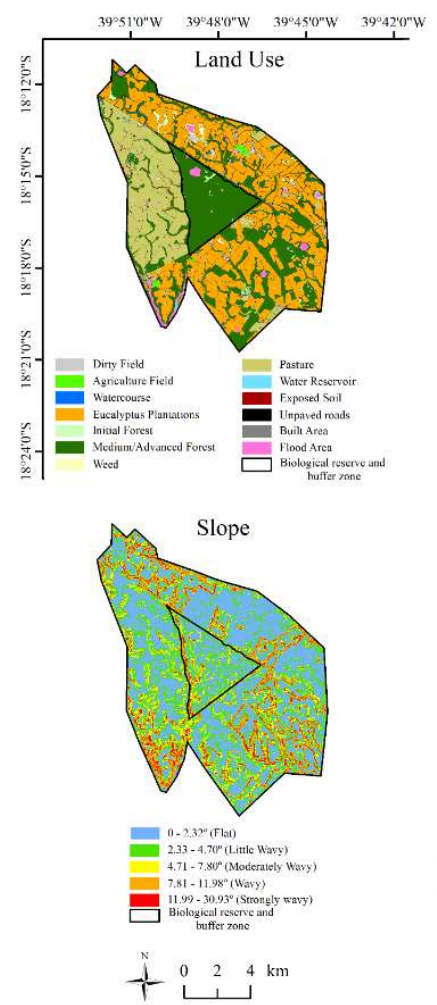

Figure 3: Spatial distribution of land use, road network, slope and relief orientation classes.

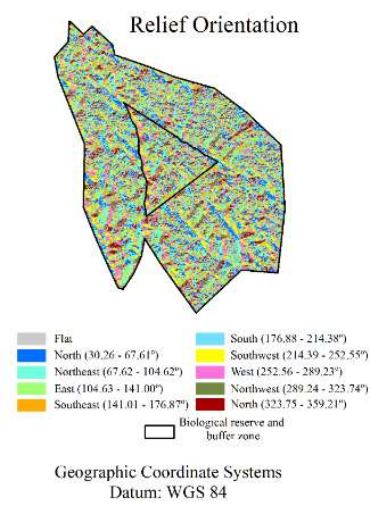

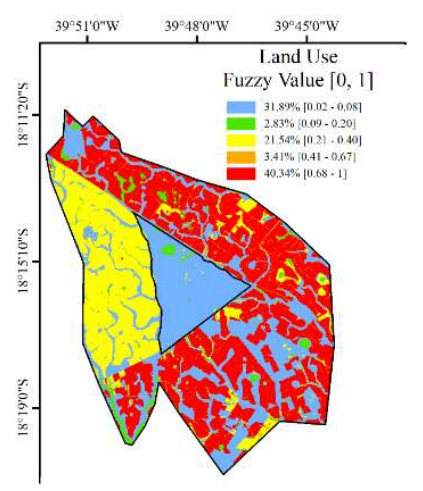
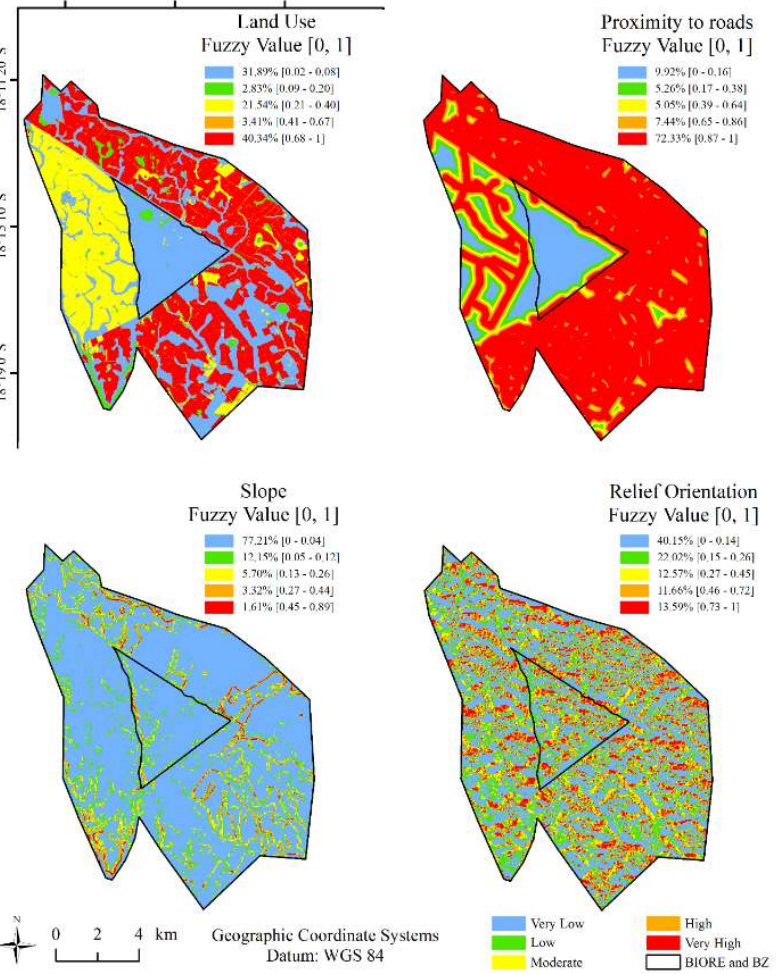

Figure 4: Fuzzy values for the variables of land use, road network, slope and relief orientation.

A total of 47 fire outbreaks were recorded in the study area between January 1, 2008 and January 1, 2019, as shown in Table 5 together with annual rainfall. 
Table 5: Occurrence of fires and rainfall in the Biological Reserve of Córrego Grande and its buffer zone between the years 2008 and 2019.

\begin{tabular}{llll}
\hline \multirow{2}{*}{ Year } & \multicolumn{2}{l}{ Number of Occurrences } & Annual rainfall $(\mathrm{mm})$ \\
\cline { 2 - 3 } & BIORE Interior & Buffer Zone & $1,553.0$ \\
2008 & - & - & $1,097.2$ \\
2009 & - & - & $1,041.0$ \\
2010 & - & - & $1,414.0$ \\
2011 & - & 2 & 990.6 \\
2013 & - & 5 & $1,197.0$ \\
2014 & - & 5 & 889.8 \\
2015 & - & - & 757.6 \\
2016 & 1 & 17 & 744.2 \\
2017 & - & 16 & $1,137.6$ \\
2018 & - & 1 & $1,401.4$ \\
\hline Total & - & - & - \\
\hline
\end{tabular}

It was possible to obtain the forest fire risk map of the study area by applying the Fuzzy Gamma overlay technique and adding the fire outbreak sites in the study area (Figure 5).

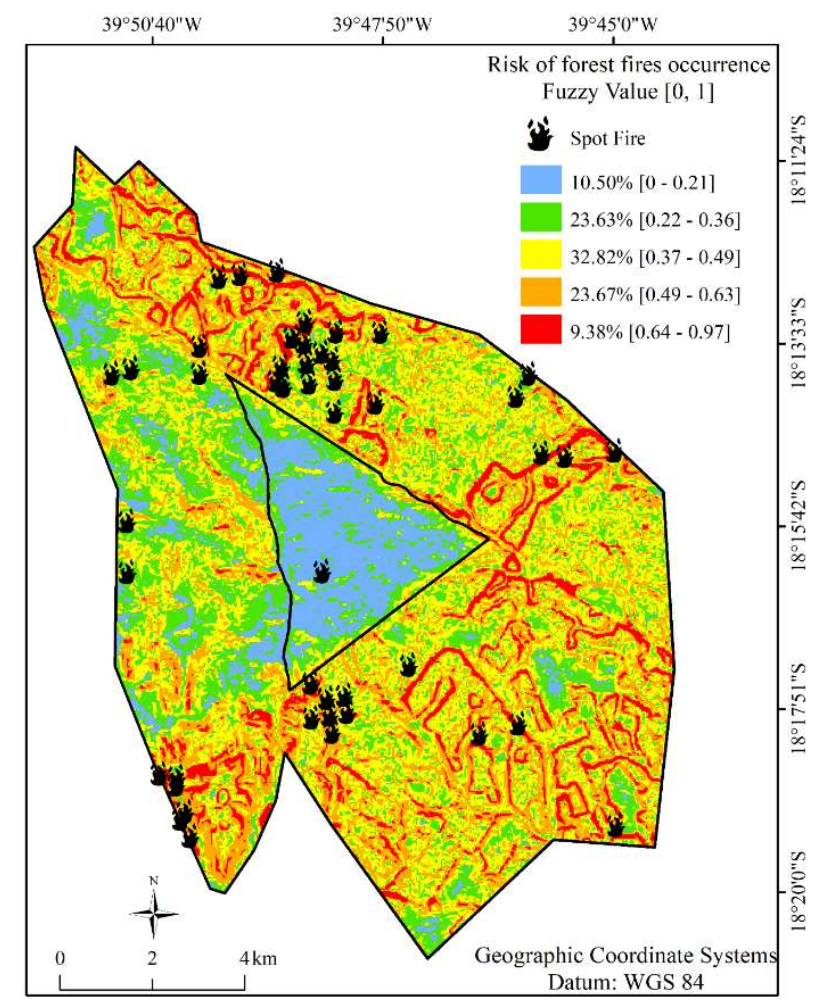

Figure 5: Zoning of the Risk of Occurrence of Forest Fires in the Córrego Grande Biological Reserve and its buffer zone.

Table 6 represents the occurrences of fires in the study area by risk class.

Table 6: Occurrence of spot fires in the Biological Reserve of Córrego Grande and its buffer zone by risk class.

\begin{tabular}{lll}
\hline Risk classes & Number of spot fires (un.) & Percentage (\%) \\
\hline Very Low & 3 & 6.38 \\
Low & 11 & 23.40 \\
Moderate & 13 & 27.66 \\
High & 15 & 31.92 \\
Very High & 5 & 10.64 \\
\hline Total & 47 & 100 \\
\hline
\end{tabular}

\section{DISCUSSION}

The information linked to the digitalized representations of land use are important tools for 
management, planning and understanding the spatial organization patterns of a given environment (GOBBO et al., 2016). This type of information enables identifying the regions with the highest risk of fire occurrences and consequently those needed to increase combat efficiency and prevention techniques.

The land use class composed of forest plantations of the Eucalyptus genus has the highest individual representation in the study area (39.47\%), followed by forests in the medium/advanced regeneration stage $(31.18 \%)$ and by pasture (20.00\%) (Table 4 and Figure 3 ). The other classes together accounted for $9.34 \%$, with the built-up areas being the least present $(0.015 \%)$.

It is important to clarify that about $95 \%$ of the interior of BIORE is composed of the class of forests in the medium/advanced regeneration stage, and that only $0.38 \%$ concerns anthropic activities (built areas, unpaved roads and eucalyptus plantations), respecting the full preservation restrictions set out in Law No. 9,985 of July 2000 (BRASIL, 2000). On the other hand, the buffer zone comprises $44 \%$ of eucalyptus plantations due to the proximity between the study area and the private production areas of forestry companies present in the states of Espírito Santo and Bahia.

The presence of silvicultural activities in the study area is an important factor to be considered when drawing up fire risk maps. This type of vegetation is characterized by the deposit of large amounts of combustible material in the soil, thus increasing the risk of occurrence. In addition, the frequent human presence and intense mechanized activities during the forest production process can translate into a risk of forest fires.

Another point of concern regarding the spatial distribution of land use classes in the study area is that only $0.32 \%$ of the area is represented by water courses and reservoirs. Obtaining water is one of the greatest difficulties during firefighting, as regions of occurrence are often far from places with water availability (FIEDLER et al., 2015). Thus, the authors indicated the use of chemical products in their study which reduce the need for water and increase the efficiency in combating claims. In addition, another strategy that can be adopted is to construct reservoirs or artesian wells with coupling and pumping systems for combat vehicles in strategic locations in the area.

The risk of fire occurrence within BIORE in which medium/advanced forests predominate is mainly classified as: "Very low" (0.02 - 0.08), "Low" (0.09 - 0.20) and "Moderate" (0.21 - 0.40) (Figure 4). The opposite happens in the buffer zone, where eucalyptus plantations predominate, with the main occurrence classes of: "Very high" and "Moderate".

In relation to the use and occupation of land, it can generally be seen that the Unit has $43.75 \%$ of its area under the risk occurrence classes of "Very high" and "High", elucidating the need for effective prevention. However, the areas with occurrence risk of "Very low" and "Low" also present a reasonably high result of $34.72 \%$. The Moderate class of occurrence risks in this variable also presents values which cannot be ignored, because $21.54 \%$ represents 3,140 hectares in terms of area.

The vulnerability to the occurrence of forest fires is directly related to the proximity of roads (MOTA et al., 2019). This is due to the fact that the presence of man in the vicinity of forests naturally increases the possibility of fires (SOARES NETO et al., 2016). Although there is a directly proportional relationship between 
the distribution of roads and the risk of fire occurring, managers must understand that the lower the availability of roads in the area, the more difficult the combat becomes due to the difficulty of locomotion of vehicles, brigades and equipment without roads.

Therefore, according to Table 1 and Figure 3, it is possible to perceive a good distribution of the road network in the study area, being represented by a perimeter of 1,030.04 km divided between the three classes of roads (primary, secondary and tertiary). The roads with the largest perimeters within the area are secondary $(986.49 \mathrm{~km})$, primary $(42.38 \mathrm{~km})$ and tertiary $(1.17 \mathrm{~km})$, respectively.

Studies by Tian et al. (2013) and Torres et al. (2017b) corroborate the choice for the relevance function (Fuzzy Small) used to determine the influence of the proximity of roads, as they showed that the occurrence of fire outbreaks decreases as the area moves away from the road network. Thus, in Figure 4 it is possible to see that the road distribution in the studied perimeter had a direct influence on the $79.77 \%$ in the risk classes for the occurrence of "high" and "very high" fires. Another fact to be observed in the figure is that most roads were included in the $9.92 \%$ of the "very low" fire risk class, as there is little influence from the roads inside BIORE.

Topographic variables also have a strong influence on RFFO, such as the relief inclination and orientation (MOTA et al., 2019; NADERPOUR et al., 2019; VENKATESH et al., 2020; ÇOLAK et al., 2020). Thus, it is possible to notice from Figure 3 that the study area does not present high slopes, with $30.93 \%$ being the highest inclination found. Most of the area is classified as flat or gently undulating. This characteristic is reflected in the $89.37 \%$ of the "very low" (0-0 0.04) and "low" $0.05-0.12)$ risk classes in the Fuzzy set (Figure 4).

The face which most influences the risk of fire occurrence in this study is the North due to the speed and strength of strong winds and solar radiation index. In the study by Mota et al. (2019), the North face was classified as extreme risk, while in this study it was classified as "very high" risk.

In addition to the intrinsic variables in the elaborated Fuzzy model, the number of fire outbreaks in relation to the average annual precipitation is an indicator of the behavior of the accidents studied. According to Pineda et al. (2017), Strydom et al. (2017) and Mota et al. (2019), this relationship occurs because of the reduced moisture of the combustible material during the dry period, thus increasing the propensity of this material for combustion (PINEDA et al., 2017; STRYDOM et al., 2017; MOTA et al., 2019).

There is a trend towards the occurrence of fire outbreaks in times with lower precipitation values, as is the case for the years $2015(757.6 \mathrm{~mm})$ and $2016(744.2 \mathrm{~mm})$, which presented a greater number of outbreaks of 18 and 16 cases, respectively (Table 5). In contrast, there were no fires in the years 2008 (1553 $\mathrm{mm})$ and 2018 (1401.4 mm).

The risk zoning for the occurrence of forest fires was generated after combining all of the variables (Figure 5). The result of the Fuzzy Gamma overlay equation generated an image with the pixel sets varying from 0 to 0.97 , with the highest occurrence risk represented by the class from 0.64 to 0.97 (very high risk) and a red color. This class had an influence on $9.38 \%$ of the extension of the study area.

In addition to the influence of the roads, the geolocation of the very high risk classes elucidates the 
importance of the land use classes, such as eucalyptus plantations, which are concentrated in the BIORE's buffer zone, which was exactly where the risk classes "Moderate" (0.37 - 0.49) and "high" (0.49 - 0.63$)$ occurred more frequently, directly influencing the respective $32.82 \%$ and $23.67 \%$ (Figure 5).

There was a predominance of "very low" (0 - 0.21) and "low" (0.22 - 0.36) risk classes inside BIORE due to the type of vegetation cover that creates a characteristic microclimate with milder temperature, higher humidity, less wind circulation, absence of roads and consequently of human contact and the mild declivity. These two classes together added $34.13 \%$ of influence over the study area, corroborating with the results of Table 5 which showed that only $2.72 \%$ of the outbreaks occurred in that place. This provides evidence of the influence of the "moderate", "high" and "very high" classes which together accounted for $65.87 \%$ of the area.

It is noticed that $70.22 \%$ of the outbreaks occurred in the period studied in this work were registered in areas of influence of the "moderate", "high" and "very high" risk classes, demonstrating the effectiveness of the methodology used (Table 6).

\section{CONCLUSIONS}

The high historical percentage of the occurrence of outbreaks of forest fires in areas considered of moderate to very high risk to the occurrence of forest fires validates the proposed model and allows to affirm that the use of a Fuzzy model can be applied in predicting the occurrence of forest fires. In fact, it was so accurate that the methodology was able to affirm that the most influential variable on the risk level of fire occurrence is the forest road network, as it is an environment with a continuous flow of people, vehicles and heavy machinery, as well as the type of use and occupation of land present on the margins, which in this study was classified with the maximum risk of fire occurrence. Thus, the proposed methodology can be applied to any other areas and types of land cover.

\section{REFERENCES}

ALVARES, C. A.; STAPE, J. L.; SENTELHAS, P. C.; GONÇALVES, J. L. M.; SPAROVEK, G.. Köppen's climate classification map for Brazil. Meteorologische Zeitschrift, v.22, n.6, p.711-728, 2014. DOI: https://doi.org/10.1127/0941-2948/2013/0507

ANDRIĆ, J. M.; LU, D. G.. Fuzzy methods for prediction of seismic resilience of bridges. International Journal of Disaster Risk Reduction, v.22, p.458-468, 2017. DOI: https://doi.org/10.1016/j.ijdrr.2017.01.001

BRASIL. Ministério do Meio Ambiente. Número de incêndios florestais é o menor em 20 anos. Brasília: MMA, 2018.

BRASIL. Lei n. 9.985, de $\mathbf{1 8}$ de julho de 2000. SNUC - Sistema Nacional de Unidades de Conservação, 2000. Regulamenta o art. 225, § 1o, incisos I, II, III e VII da Constituição Federal, institui o Sistema Nacional de Unidades de Conservação da Natureza e dá outras providências. Brasília: DOU, 2000.

CAI, T.; LI, X.; DING, X.; WANG, J.; ZHAN, J.. Flood risk assessment based on hydrodynamic model and fuzzy comprehensive evaluation with GIS technique. International
Journal of Disaster Risk Reduction, v.35, p.101077, 2019. DOI: https://doi.org/10.1016/j.ijdrr.2019.101077

ÇOLAK, E.; SUNAR, F.. Evaluation of forest fire risk in the Mediterranean Turkish forests: a case study of Menderes region, Izmir. International Journal of Disaster Risk Reduction, v.45, p.101479, 2020. DOI: https://doi.org/10.1016/j.ijdrr.2020.101479

EUGENIO, F. C.; SANTOS, A. R.; FIEDLER, N. C.; RIBEIRO, G. A.; SILVA, A. G.; SANTOS, A. B.; PANETO, G. G.; SCHETTINO, V. R.. Applying GIS to develop a model for forest fire risk: $A$ case study in Espírito Santo, Brazil. Journal of Environmental Management, v.173, p.65-71, 2016. DOI: https://doi.org/10.1016/j.jenvman.2016.02.021

FIEDLER, N. C.; CANZIAN, W. P.; MAFIA, R. G.; RIBEIRO, G. A.; KRAUSE JÚNIOR, J.. Intensidade de queima de diferentes retardantes de fogo. Revista Árvore, v.39, n.4, p.691-696, 2015. DOI: https://doi.org/10.1590/010067622015000400011 
BRANCO, W. R. F.; SANTOS, A. R.; PEZZOPANE, J. E. M.; SANTOS, A. B.; ALEXANDRE, R. S.; BERNARDES, V. P.; SILVA, R. G.; SOUZA, K. B.; MOURA, M. M.. Space-time analysis of vegetation trends and drought occurrence in domain area of tropical forest. Journal of Environmental Management, v.246, p.384-396, 2019. DOI:

https://doi.org/10.1016/j.jenvman.2019.05.097

GAGLIONE, S.; ANGRISANO, A.; INNAC, A.; PIZZO, S. D.; MARATEA, A.. Fuzzy logic applied to GNSS. Measurement. Journal of the International Measurement Confederation, v.136, p.314-322, 2019. DOI:

https://doi.org/10.1016/j.measurement.2018.12.103

GOBBO, S. D. A.; GARCIA, R. F.; AMARAL, A. A.; EUGENIO, F. C.; ALVAREZ, C. R. S.; LUPPI, A. S. L.. Uso da terra no entorno do PARNA-Caparaó: Preocupação com Incêndios florestais. Floresta e Ambiente, v.23, p.350-361, 2016. DOI: https://doi.org/10.1590/2179-8087.110114

HERAWATI, H.; SANTOSO, H.. Tropical forest susceptibility to and risk of fire under changing climate: A review of fire nature, policy and institutions in Indonesia. Forest Policy and Economy, v.13, n.4, p.227-233, 2011. DOI: https://doi.org/10.1016/j.forpol.2011.02.006

JIA, X.; MOREL, G.; MARTELL-FLORE, H.; HISSEL, F.; BATOZ, J.. Fuzzy logic based decision support for mass evacuations of cities prone to coastal or river floods. Environmental Modelling \& Software, v.85, p.1-10, 2016. DOI: https://doi.org/10.1016/j.envsoft.2016.07.018

JUVANHOL, R. S.; FIEDLER, N. C.; SANTOS, A. R.. Modelagem de risco de incêndios em florestas naturais com o uso de geotecnologias. In: SANTOS, A. R.; RIBEIRO, C. A. A. S.; PELUZIO, J. B. E.; PELUZIO, T. M. O.; SANTOS, G. M. A. D. A.; MOREIRA, G. L.; MAGALHÃES, I. A. L.. Geotecnologias \& análise ambiental: aplicações práticas. Alegre: CAUFES, 2015. p.160-172.

MACHADO NETO, A. P.; BRANDÃO, C. F. L. S.; DUARTE, B.; ALMIR, J.; MARANGON, L. C.; FELICIANO, A. L. P.. Densidade e poder calorífico como base para prevenção de incêndios florestais sob linhas de Transmissão. Nativa, v.3, n.1, p.10-15, 2015. DOI: https://doi.org/10.14583/23187670.v03n01a02

MORA, J. L.; ARMAS-HERRERA, C. M.; GUERRA, J. A.; ARBELO, C. D.; RODRÍGUEZ-RODRÍGUEZ, A.; PINO J. S. N.. A Comparative Study of Long-Term Effects on Fire-Affected Volcanic Soils in Two Different Ecosystems in the Canary Islands. Land Degradation \& Development, v.27, p.14891500, 2016. DOI: https://doi.org/10.1002//dr.2458

MOTA, P. H. S.; ROCHA, S. J. S. S.; CASTRO, N. L. M.; MARCATTI, G. E.; FRANÇA, L. C. J.; SCHETTINI, B. L. S.; VILLANOVA, P. H.; SANTOS, H. T.; SANTOS, A. R.. Forest fire hazard zoning in Mato Grosso State, Brazil. Land use policy, v.88, p.104206, 2019. DOI:

https://doi.org/10.1016/j.landusepol.2019.104206

MURILLO, J. F. M.; HUESO-GONZÁLEZ, P.; RUIZ-SINOGA, J. D.; LAVEE, H.. Short-term Experimental Fire Effects in Soil and Water Losses in Southern of Spain.Land Degradation and Development, v.27, n.5, p.1513-1522, 2016. DOI: https://doi.org/10.1002//dr.2504
MURRAY-SMITH, C.; BRUMMITT, N. A.; OLIVEIRA FILHO, A. T.; BACHMAN, S.; MOAT, J.; LUGHADHA, E. M. N.; LUCAS, E. J.. Plant diversity hotspots in the Atlantic coastal forests of Brazil. Conservation Biology, v.23, p.151-163, 2009. DOI: https://doi.org/10.1111/j.1523-1739.2008.01075.x

MYERS, N.; MITTERMEIER, R. A.; MITTERMEIER, C. G.; FONSECA, G. A. B.; KENT, J.. Biodiversity hotspots for conservation priorities. Nature, v.408, p.853-858, 2003. DOI: https://doi.org/https://doi.org/10.1038/35002501

NADERPOUR, M.; RIZEEI, H. M.; KHAKZAD, N.; PRADHAN, B. Forest fire induced Natech risk assessment: A survey of geospatial technologies. Reliability Engineering and System Safety, v.191, p.106558, 2019. DOI: https://doi.org/10.1016/j.ress.2019.106558

OLIVEIRA, G. F.; GARCIA, A. C. L.; MONTES, M. A.; JUCÁ, J. C. L. A.; VALENTE, V. L. S.; ROHDE, C.. Are conservation units in the Caatinga biome, Brazil, efficient in the protection of biodiversity? An analysis based on the drosophilid fauna. Journal for Nature Conservation, v.34, p.145-150, 2016. DOI: https://doi.org/10.1016/i.jnc.2016.10.006

PICKARD, B. R.; MEENTEMEYER, R. K.. Validating land change models based on configuration disagreement. Computers, Environment and Urban Systems, v.77, p.101366, 2019. DOI: https://doi.org/10.1016/j.compenvurbsys.2019.101366

PINEDA, N.; RIGO, T.. The rainfall factor in lightning-ignited wildfires in Catalonia. Agricultural and Forest Meteorology, v.239, p.249-263, 2017.

https://doi.org/10.1016/j.agrformet.2017.03.016

PRENTICE, M. B.; BOWMAN, J.; MURRAY, D. L.; KLÜTSCH, C. F.; KHIDAS, K.; WILSON, P. J.. Evaluating evolutionary history and adaptive differentiation to identify conservation units of Canada lynx (Lynx canadensis). Global Ecology and Conservation, v.20, p.1-16, 2019. DOI: https://doi.org/10.1016/i.gecco.2019.e00708

ROLIM, G. D. S.; CAMARGO, M. B. P.; LANIA, G. G.; MORAES, J. F. L.. Classificação climática de Koppen e de Thornthwaite e sua aplicabilidade na determinação de zonas agroclimáticas para o estado de São Paulo. Bragantia, v.66, p.711-720, 2007. DOI: https://doi.org/10.1590/S0006$\underline{87052007000400022}$

SOARES, L. M. S.; PINHEIRO, R. F. M.. A fauna de peixes na REBIO Córrego Grande e seu entorno direto, Espírito Santo, Brasil. Boletim do Museu de Biologia Mello Leitão, v.31, p.25-57, 2013.

SOARES NETO, G. B.; BAYMA, A. P.; FARIA, K. M. S.; OLIVIERA, E. G.; MENEZES, P. H. B.. Riscos de incêndios florestais no parque nacional de Brasília - Brasil. Territorium, v.1, p.161-170, 2016. DOI: https://doi.org/10.14195/1647$\underline{7723 \quad 2313}$

SOTO, M. E. C.. The identification and assessment of areas at risk of forest fire using fuzzy methodology. Applied Geography, v.35, n.1-2, p.199-207, 2012. DOI: https://doi.org/10.1016/j.apgeog.2012.07.001

STRYDOM, S.; SAVAGE, M. J.. Potential impacts of climate change on wildfire dynamics in the midlands of KwaZuluNatal, South Africa. Climatic Change, v.143, p.385-397, 2017. 


\section{DOI: https://doi.org/10.1007/s10584-017-2019-8}

TETTO, A. F.; SOARES, R. V.; BATISTA, A. C.; WENDLING, W. T.. Incêndios florestais atendidos pela Klabin do Paraná no período de 1965 A 2009. Cerne, v.21, n.3, p.345-351, 2015 DOI: https://doi.org/10.1590/01047760201521031682

TIAN, X.; ZHAO, F.; SHU, L.; WANG, M.. Distribution characteristics and the influence factors of forest fires in China. Forest Ecology and Management, v.310, p.460-467, 2013. DOI: https://doi.org/10.1016/j.foreco.2013.08.025

TORRES, F. T. P.; LIMA, G. S.; COSTA, A. G.; FÉLIX, G. A.; SILVA JÚNIOR, M. R.. Perfil dos incêndios florestais em unidades de conservação brasileiras no período de 2008 a 2012. Floresta, v.46, n.4, p.531-541, 2017a. DOI:

https://doi.org/10.5380/rf.v46i3.44199

TORRES, F. T. P.; RIBEIRO, G. A.; MARTINS, S. V.; LIMA, G. S.. Mapeamento do risco de incêndios florestais utilizando técnicas de geoprocessamento. Floresta e Ambiente, v.24, p.25615, 2017b. DOI: https://doi.org/10.1590/21798087.025615
VAN ECK, C. M.; NUNES, J. P.; VIEIRA, D. C. S.; KEESSTRA, S.; KEIZER, J. J.. Physically-Based Modelling of the Post-Fire Runoff Response of a Forest Catchment in Central Portugal: Using Field versus Remote Sensing Based Estimates of Vegetation Recovery. Land Degradation and Development, v.27, p.1535-1544, 2016. DOI: https://doi.org/10.1002//dr.2507

VENKATESH, K.; PREETHI, K.; RAMESH, H.. Evaluating the effects of forest fire on water balance using fire susceptibility maps. Ecological Indicators, v.110, p.105856, 2020. DOI: https://doi.org/10.1016/j.ecolind.2019.105856

WHITE, B. L. A.; RIBEIRO, G. T.; SOUZA, R. M.. Caracterização do material combustível e simulação do comportamento do fogo em eucaliptais no litoral norte da Bahia, Brasil. Floresta, v.44, n.1, p.33-42, 2014. DOI:

https://doi.org/10.5380/rf.v44i1.32977

WHITE, L. A. S.; WHITE, B. L. A.; RIBEIRO, G. T.. Modelagem espacial de risco de incêndio florestal para o município de Inhambupe, Bahia, Brasil. Pesquisa Florestal Brasileira, v.36, n.85, p.41, 2016. DOI:

https://doi.org/10.4336/2016.pfb.36.85.850

A CBPC - Companhia Brasileira de Produção Científica (CNPJ: 11.221.422/0001-03) detém os direitos materiais desta publicação. Os direitos referem-se à publicação do trabalho em qualquer parte do mundo, incluindo os direitos às renovações, expansões e disseminações da contribuição, bem como outros direitos subsidiários. Todos os trabalhos publicados eletronicamente poderão posteriormente ser publicados em coletâneas impressas sob coordenação da Sustenere Publishing, da Companhia Brasileira de Produção Científica e seus parceiros autorizados. Os (as) autores (as) preservam os direitos autorais, mas não têm permissão para a publicação da contribuição em outro meio, impresso ou digital, em português ou em tradução. 